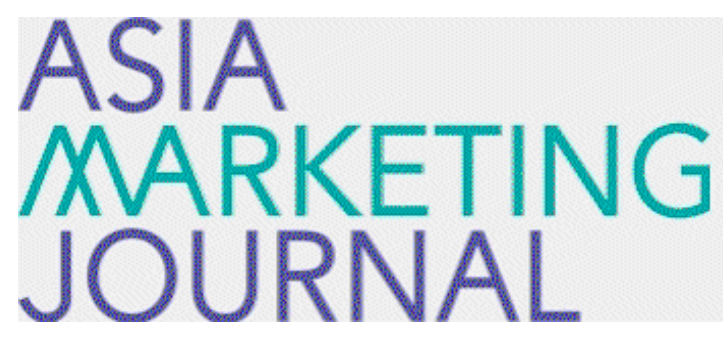

ASIA MARKETING JOURNAL

Volume 16 | Issue 1

Article 6

4-30-2014

\title{
Strong Attachment toward Human Brand and Its Implication for Life-Satisfaction and Self-efficacy
}

Mi Na Jun

Chung K. Kim

Jeong Soo Han

Kim

Jos Hua Y. Kim

Follow this and additional works at: https://amj.kma.re.kr/journal

Part of the Marketing Commons

\section{Recommended Citation}

Jun, Mi Na; Kim, Chung K.; Han, Jeong Soo; Kim; and Kim, Jos Hua Y. (2014) "Strong Attachment toward Human Brand and Its Implication for Life-Satisfaction and Self-efficacy," Asia Marketing Journal: Vol. 16 : Iss. 1 , Article 6.

Available at: https://doi.org/10.53728/2765-6500.1529

This Article is brought to you for free and open access by Asia Marketing Journal. It has been accepted for inclusion in Asia Marketing Journal by an authorized editor of Asia Marketing Journal. 


\title{
Strong Attachment toward Human Brand and Its Implication for Life-Satisfaction and Self-efficacy: Hero versus Celebrity
}

\author{
Mina Jun* \\ Chung K. Kim** \\ Jeongsoo Han*** \\ Miyea Kim**** \\ Joshua Y. Kim*
}

In the year 2013, Warren Buffett was named one of the most influential people of the year by TIME magazine. When people are exposed to such news, they show strong interest in who the influential people are and how those people became so successful. Likewise, people show strong attachment to other prominent figures as well. This social phenomenon indicates that people perceive well-known persona like business leaders, TV stars or sports stars etc. as human brands of intangible assets. As the role of these human brands is becoming more important, people tend to develop stronger attachment toward them. Another notable modern social phenomenon is people's pursuit of lifesatisfaction and social well-being. People desire to increase their quality of life by having quality time with family and friends, and also by building attachment towards celebrities, sports stars, and so on.

The main objective of this study is to examine how attachment toward human brands affects quality of life. While existing studies on human brands examined antecedents of attachment, e.g., some needs fulfillment such as A-R-C needs (autonomy, relatedness and competence needs) fulfillment, this study focuses on the outcome variables of attachment, e.g., how attachment toward human brands affects stress relief and life satisfaction through self-efficacy. Based on previous research, we divided human brands into two types: heroes and celebrities. Heroes are defined as people who have considerable and lasting importance on both societal and individual levels, and celebrities are defined as people who are well-known but have little or no short-term impact on society and individual levels.

This study focuses on how attachment toward each type of human brands, celebrities and heroes, affects the quality of life or well-being. This study focuses on three important outcome variables;

\footnotetext{
* Ph.D., Graduate School of Business, Sungkyunkwan University(alskwjs@skku.edu)

** Professor, Graduate School of Business, Sungkyunkwan University(kimkim@skku.edu)

*** Ph.D., Graduate School of Business, Sungkyunkwan University(js3916@gmail.com), Corresponding author

**** Ph.D., Graduate School of Business, Sungkyunkwan University(cally0615@skku.edu)

***** Fulbright Scholar, Korean-American Educational Commission(jyk42@cornell.edu)
} 
stress relief, life satisfaction, and self-efficacy, (three variables) which have been recently gaining importance, especially in the domain of positive psychology.

Major findings from the present study show that although celebrities draw attachment from people by providing fun and entertainment or providing stress relief, they have weak influences on the wellbeing or efficacy of individuals at a deeper level. In contrast, attachment toward heroes helps people live better by providing meaning and positively influencing life satisfaction through self-efficacy (Frankl 1997). These results are consistent with the main tenet of 'positive psychology' which seeks "to find and nurture genius and talent and to make normal life more fulfilling" (Seligman and Csikszentmihalyi 2000). Considering the fact that certain celebrities are perceived as heroes to some, we can conclude that celebrities can become heroes if they provide meaning and value to the lives of people.

This study contributes to the research stream of human brands since the most current leading research (e.g., Thomson 2006) indicated the need to look at the resulting effect of attachment on life satisfaction through self-efficacy. Another important contribution is that we empirically documented the different effects of celebrities and heroes. As expected, this study shows that heroes more deeply influence the lives of individuals in the long term while celebrities do so rather shallowly in the short term. The issues of the influence of heroes on the individuals' lives need to be further investigated in relation with the perspective of positive psychology.

Key words: Human Brand, Hero, Celebrity, Attachment, Self-efficacy, Life-satisfaction, Stress Relief

\section{Introduction}

Every year TIME and FORBES announce a list of the most influential and popular people from various fields. In the year 2013, for example, Warren Buffett and Beyoncé were named as the most influential people of the year. Every time they announce the list, the world shows interest in individuals who made the list. This social phenomenon indicates that people perceive well-known persons like business leaders, TV stars or sports stars etc. as human brands of intangible assets (Thomson 2006). As the role of these human brands is becoming increasingly important, people tend to develop stronger attachment toward them.

Another notable modern social phenomenon these days is people's pursuit of satisfaction with life or social well-being (Oishi 2001; Lee and Yu 2011; Kim et.al. 2013). They seek to increase their quality of life by having quality time with family and friends, and also by building attachment with celebrities, sports stars, and so on. Since people care about their wellbeing, more companies are interested in enhancing the well-being of their customers while preserving the well-being of the firm's other 
stakeholders (Lee and Sirgy 2004). Quality of life marketing studies show that enhanced consumers' well-being results in positive wordof-mouth and company goodwill. This is because when customers perceive that a company tries to enhance their well-being, they feel that they can trust the company (Lee and Sirgy 2004; Szymanski and Henard 2001). Therefore, marketing activities of companies need to be designed in ways to enhance consumers' well-being, and the study regarding consumers' well-being is gaining significance. However, majority of existing marketing studies have focused on how to increase consumer loyalty or company profit without considering well-being of their consumers.

Thus, the central purpose of this article is to address how the attachment toward human brands affects consumers' quality of life such as self-efficacy and life satisfaction. Since the existing studies on human brands examined antecedents of attachment, e.g., some needs fulfillment such as A-R-C needs (autonomy, relatedness and competence needs) fulfillment (e.g., Thomson 2006; Ahn and Lee 2010), this study focuses on the outcome variables of attachment, e.g., how the attachment toward human brands affects consumers' well-being. Based on previous researches, we divided human brands into two types in our study: heroes and celebrities. Heroes are defined as people who have considerable and lasting importance on both societal and individual levels while ce- lebrities are defined as people who are wellknown but have little or no short-term impact on societal and individual levels (North, Bland, and Ellis 2005).

In our study, we focus on how attachment toward each type of human brands, celebrities and heroes, affects the quality of life or wellbeing. This study focuses on three important outcome variables; stress relief, life satisfaction and self-efficacy, which has recently been gaining importance especially in the domain of positive psychology (Seligman and Csikszentmihalyi 2000).

In the section of literature review that follows, more details about attachment, types of human brands (celebrities and heroes), and the outcome variables (life satisfaction, self-efficacy, and stress relief) will be reviewed. Next, hypotheses on the different effects of celebrities and heroes on stress relief and life satisfaction through self-efficacy will be provided. Then, empirical study and results will be discussed, followed by summary and conclusion. Finally, academic and managerial contribution and $\mathrm{fu}^{-}$ ture research will be presented.

\section{Literature Review}

Most previous research on brand attachment focus on how attachments affect brand commitment, brand loyalty, and so on at corporate 
or products levels (Wallendorf and Arnould 1988; Thomson, Maclnnis, and Park 2005; Park, MacInnis, and Priester 2006). Recently, Park, MacInnis and Priester (2006) proposed that attachment toward human brands positively affect consumers' response to brand they are endorsing. However, present study focuses on how the attachment toward human brands can affect consumers' quality of life such as life satisfaction, self-efficacy, and stress relief. In his human brands study, Thomson (2006) proposed that the study of how human brands can affect personal life should be initiated. Kim et al. (2010) also empirically documented that strong attachment toward human brands generally enhances people's quality of life.

\subsection{Types of Human Brands}

Human brands that were used in previous studies include actors, sports stars, singers, politicians, and etc. Various definitions of human brands have been proposed. Rein, Kottler, and Stoller (1987) advocated that human brands are "a product of the marriage of entertainment and fame (p. 21)" McCracken (1989) and Reeves (1988) offered that human brands are created through the mass communication to trigger positive emotional responses in the audience. Rinda, Pollock and Hayward (2006) proposed that "individual such as Oprah Winfrey and Michael Jordan demonstrate that individual celebrities can convert their name into valuable brands, thereby further increasing the value they can appropriate from their celebrity status (p. 53)" Thomson (2006) defined human brands as "any well-known persons who is the subject of marketing communications efforts. (p.104)"

However, North, Bland, and Ellis (2005) tried to distinguish heroes from celebrities in their research on human brands. They defined heroes as "someone who produced ideas or objects of considerable and lasting importance to society, and who may or may not be well-known" and defined celebrities as "someone who are well-known but who are perceived as producing ideas or objects that have had less(or no) impact on society for a shorter period of time (p. 40)." Holt (2006) proposed that unlike celebrities, heroes or icons, brands face social issues that reflect people' contradictions and desire. Pretzinger (1976) and Sullivan and Venter(2005) suggested that heroes can represent an ideal self-image. Pleiss and Feldhusen (1995) suggested that "most definitions of heroes involve some reference to values and to the hero as an agent of significant societal change (p. 164).”

Based on previous studies on human brands, we suppose that heroes and celebrities would have different influences on people. As such, we categorized human brands into heroes and celebrities. We define heroes as people who have considerable and lasting importance on both societal and individual levels and celebrities as people who are well-known but have little or no impact on societal and individual levels for 
a shorter period of time for the present study.

\subsection{Self-Efficacy and Life Satisfaction}

Bandura (2002) defined self-efficacy as 'individuals' opinions or assessments of their ability to organize their own behavior and do things in such a way to be satisfied with outcome." Four important sources of information such as mastery experience, vicarious experience, verbal persuasion, and emotional arousal are relevant in forming self-efficacy (Bandura 1977: Steyn and Mynhardt 2008). First, mastery experience is the most influential source for self-efficacy. Performing task successfully reinforces self-efficacy, but failure undermines self-efficacy (Steyn and Mynhardt 2008). Second, vicarious experience can be explained by "If they can do that, I can do that.' People identify with models or models' ability through vicarious experience. Third, verbal persuasion is relevant with encouraging and discouraging people, and influences levels of self-confidence. Fourth, emotional arousal can be elicited by stressful situations. Thus, emotional arousal can undermine perceived self-efficacy in coping with stressful situations (Bandura 1977). According to the domain of positive psychology, self-efficacy is considered as feelings of confidence that they can accomplish with the task they face (Seligman and Csikszentmihalyi 2000).

Life satisfaction is a cognitive and judgmental process. Shin and Johnson (1978) defined life satisfaction as "a global assessment of a person's quality of life according to his chosen criteria."

Recently, as the new social phenomenon of people' pursuit of satisfaction with life and well-being is spreading, marketing researchers are showing interest in quality of life. As a result, marketing activities of companies are performed not only in the ways to build loyalty to brands, but also in the ways to improve consumers' quality of life. Sirgy et al. (1995) claimed that improving consumers' quality of life should be the central purpose of marketing.

\subsection{Stress Relief}

Stress refers to any threat, either real or perceived, to the well-being (Kumar 2013). Hence, stress relief means relieving any threat to the one's well-being and is one of the key factors to a happy and successful life in modern society. Stress generates many symptoms that vary according to individuals, conditions, and harshness. These can include physical health weakening as well as psychological depression (Lazarus and Folkman 1984). Although stress is often considered a subjective experience, levels of stress are measureable using numerous physiological checks, similar to those used in testers. Relieving stress provide positive feelings and emotions of being in control of one's life (Cohen, Kamarck, and Mermelstein 1983). Due to the importance of stress relief, many practical 
stress management techniques and methods are developed.

\section{Hypothesis}

\subsection{The Effects of Attachment to Heroes (vs. Celebrities) on Self- Efficacy and Stress Relief}

As mentioned earlier, people reinforce or undermine self-efficacy through vicarious experience (Bandura 1977; Steyn and Mynhardt 2008). In other words, people identify with a model human brand's considerable achievements, which have positive impacts on self-efficacy. We defined heroes as people who confront hardships and who have considerable and lasting importance at both society and individual levels. Thus, attachment toward heroes would have positive impact on self-efficacy. When people feel that somebody, especially their hero, is supportive or encouraging, they tend to more frequently engage in behaviors such as trying new things, challenging the limit, and setting higher goals. This is because they believe that someone is available to assist them when they are in need or even when they fail. However, celebrities are people who are well-known but who have little or no impact on both societal and individual levels for a shorter period of time. Therefore, we predict that attachment toward heroes would have a more positive impact on self-efficacy while attachment toward celebrities would have minimal impact on self-efficacy.

It is expected that attachment to celebrities or heroes has a positive effect on stress relief. When people feel emotionally attached to a certain object, they experience positive emotions, which in turn help them get rid of negative feelings like stress (Bowlby 1988). Another previous study also supports our argument. When people form a secure attachment with someone, they develop a well-balanced mind and feeling of happiness (Belk 1988). This can lead to increased positive emotions and decreased negative emotions such as stress, worry, and anxiety. More recently, Kobak et al. (2006) suggested having attachment objects (human brands in current context) enables people to regulate the stress more effectively. Therefore, attachment to heroes and celebrities can lead to stress relief. However, we expect that attachment to celebrities and attachment to heroes differ in their strength to relieve stress.

Heroes can be role models that people want to follow and imitate (Klapp 1969; Pretzinger 1976). Therefore, people feel attached to heroes who can reflect their self-identities and give meaning to life, which causes people to feel competence and courage. On the other hand, although celebrities can be the object of attachment, people tend to value the entertainment value of celebrities. Thus, the value that celebrities can provide only stays on the enter- 
tainment level, which would have little impact on quality of life in the long run. According to Frankl (1997), people pursue three types of value, entertainment, power, and meaning, but not all of these three values lead to life satisfaction. Of these three values, Frankl (1997) suggested that entertainment and power values may represent short-term value that celebrities have, but meaning value may represent long-term value that heroes have. North, Bland, and Ellis (2005) also suggested that each type of human brand has a different impact on people, so celebrities and heroes should affect people's quality of life in different ways. Therefore, we expect that attachment toward heroes, which is related to the value of meaning would have a stronger positive impact on self-efficacy, while attachment toward celebrities, with its value of entertainment, would have a stronger positive impact on stress relief. Thus, we propose following hypotheses.

\section{H1: Attachment to heroes has a stronger} positive effect on self-efficacy than attachment to celebrities does.

H2: Attachment to celebrities has a stronger positive effect on stress relief than attachment to heroes does.

\subsection{The Effects of Self-efficacy on Life Satisfaction}

It is generally believed that the more people feel the sense of "I can," the more they feel satisfaction in life. Recent studies also show that self-efficacy, the belief in one's ability to control our behavior, environment, feelings, and thought, is very important for happiness and psychological well-being (Maddux 2009). Selfefficacy is a major tenet of psychological health, and is closely linked to a number of psychological problems. Low level of self-efficacy is a main symptom of depressed people, who usually believe that they are less capable of behaving efficiently in many important domains of life, regardless of their actual capabilities (Maddux and Meier 1995; Bandura 1997).

Moreover, self-efficacy positively influences goal development, efficiency and effectiveness in problem solving, which eventually leads to enhanced life satisfaction. Efficacy also enables people to come up with better solutions and achievements. (Maddux 2009). "When faced with a difficult decision, people who have confidence in their ability to solve problems use their cognitive resources more effectively than those who doubt their cognitive skills" (Maddux 2009, p.339). Thus, people with high level of self-efficacy can cope with a difficult task with confidence and thus are more likely to accomplish their goal. These experiences of achievements enrich one's life and ultimately increase one's quality of life. Therefore, we propose our hypothesis:

H3: Self-efficacy has a positive effect on 
life satisfaction.

\section{Methods}

In this study, human brand is divided into either celebrities or heroes according to the conceptual definition from the existing literature. The major concepts such as attachment, stress relief, self-efficacy, and life satisfaction were also measured accordingly.

\subsection{Sample and Measurement}

We conducted a survey of young people including college students and employees of major companies. At the beginning of the survey, we provided the definitions of celebrities and heroes, and asked them to first choose their most favorite celebrity and hero respectively. Heroes were defined as people who have considerable and lasting importance at both societal and individual levels because they have confronted a serious problem, difficulty, or conflict which challenges an individual's ideas and goals. Celebrities were defined as people who are well-known but are perceived as producing ideas or objects that have had less (or no) impact on society for a shorter period of time. Given the choice of their most favorite celebrity and hero, the respondents were asked to answer to the questions about attachment, stress relief, life satisfaction, and self-efficacy.

A total of 307 usable samples were compiled for our analysis including basic statistic and linear structural model such as AMOS program.

〈Table 1〉 Major Items and Measures for Analysis

\begin{tabular}{clc}
\hline \hline \multicolumn{1}{c}{ Items } & \multicolumn{1}{c}{ Measures } & References \\
\hline \multirow{2}{*}{$\begin{array}{c}\text { Attachment to } \\
\text { hero/celebrity }\end{array}$} & $\begin{array}{l}\text { I miss XYZ when XYZ is not around. } \\
\text { If XYZ were permanently gone from my life, I'd be upset. } \\
\text { Losing XYZ forever would be distressing to me. }\end{array}$ & $\begin{array}{c}\text { Thomson } \\
\text { (2006) }\end{array}$ \\
\hline \multirow{2}{*}{ Stress relief } & $\begin{array}{l}\text { Seeing XYZ gives me the feeling of happiness, joy, and excitement. } \\
\text { Seeing XYZ gives me the feeling of warmth and love. }\end{array}$ & $\begin{array}{c}\text { Watson, Clark, and } \\
\text { Tellegen (1994) }\end{array}$ \\
\hline \multirow{2}{*}{ Self-efficacy } & It is easy for me to stick to my aims and accomplish my goals. & \\
& $\begin{array}{l}\text { I am confident that I can deal efficiently with an unexpected event. } \\
\text { Thanks to my resourcefulness, I know how to handle unforeseen }\end{array}$ & Bandura (1977) \\
& situations. & \\
\hline \multirow{2}{*}{ Life satisfaction } & I am satisfied with my life. & Diener et al. (1985) \\
& $\begin{array}{l}\text { The conditions of my life are excellent. } \\
\text { So far I have gotten the important things I want in life. }\end{array}$ \\
\hline
\end{tabular}




\subsection{Manipulation Check}

We conducted the manipulation check to confirm that respondents answer to survey questions with understanding the difference between concepts of heroes and celebrities. Questions for the manipulation check were developed based on conceptual definitions of heroes and celebrities. Two questions "The hero or celebrity has considerable and lasting influence on my value and I admire him or her' and 'The hero or celebrity produced ideas or objects of considerable and lasting importance to society' were asked to respondents on a 7-point scale. As a result of the manipulation check, we found that the average score for celebrities was 4.43 and the average score for heroes was 6.19. T-test between average scores for celebrities and heroes shows that there are significant difference between average scores for heroes and celebrities $(t=-20.439)$.

\section{Major Results}

Testing hypotheses is achieved by estimating the coefficients of paths in the linear structural equation model. Before we go to the hypotheses tests, we first conducted reliability and validity test of our construct measures.

\subsection{Reliability and Validity}

In order to test the reliability and validity, we first conducted Cronbach's Alpha test, Exploratory Factor Analysis (EFA), and Confirmatory Factor Analysis (CFA). The results are summarized in Table 2. Generally, we assume high reliability if the Alpha value is above 0.7 (Nunnally 1978). All of Cronbach's Alpha values are above 0.7. It indicates that the measures embody strong confidence and internal consistency.

Also to test the validity of the major constructs, we ran EFA. Principal component analysis and Varimax rotation were carried out to $\mathrm{ex}^{-}$ tract primary features. As shown in table 2, the major constructs turned out to have convergent validity and discriminant validity.

To more formally test reliability and validity, we conducted CFA. The model fits of CFA $(\mathrm{CMIN} / \mathrm{DF}=2.821, \mathrm{CFI}=.928, \mathrm{NFI}=.895$, $\mathrm{IFI}=.930$, TLI $=.895$, and RFI $=.846)$ generally satisfy the required level. The composite reliability was calculated using the results of CFA. As shown in Table 2, all values of composite reliability are high and exceed the threshold value of .6, confirming that the measures are reliable and representative (Bagozzi and Yi 1988). In addition, all the factor loadings are significant $(p<.01)$, which Bagozzi, Yi, and Phillips (1991) suggest as a criterion of convergent validity. Overall, our measurement scales show sufficient reliability and validity. 
〈Table 2〉 The Results of Reliability and Validity Test

\begin{tabular}{|c|c|c|c|c|c|c|}
\hline & & & $E F A$ & & $C F A$ & \\
\hline Factor & Item & Cronbach's a & Factor loading & Estimation & $(t$-value $)$ & $\begin{array}{l}\text { Composite } \\
\text { reliability }\end{array}$ \\
\hline \multirow{3}{*}{$\begin{array}{c}\text { Attachment to } \\
\text { celebrity }\end{array}$} & 1 & \multirow{3}{*}{.816} & .854 & .786 & \multirow{3}{*}{$\begin{array}{l}(14.626) \\
(11.862)\end{array}$} & \multirow{3}{*}{.671} \\
\hline & 2 & & .869 & .891 & & \\
\hline & 3 & & .552 & .679 & & \\
\hline \multirow{3}{*}{$\begin{array}{c}\text { Attachment to } \\
\text { hero }\end{array}$} & 1 & \multirow{3}{*}{.902} & .714 & .869 & \multirow{3}{*}{$\begin{array}{l}(23.031) \\
(17.855)\end{array}$} & \multirow{3}{*}{.809} \\
\hline & 2 & & .858 & .955 & & \\
\hline & 3 & & .888 & .802 & & \\
\hline \multirow{2}{*}{$\begin{array}{l}\text { Stress relief } \\
\text { (celebrity) }\end{array}$} & 1 & \multirow{2}{*}{.713} & .761 & .784 & \multirow[b]{2}{*}{$(9.396)$} & \multirow{2}{*}{.623} \\
\hline & 2 & & .836 & .724 & & \\
\hline \multirow{2}{*}{$\begin{array}{c}\text { Stress relief } \\
\text { (hero) }\end{array}$} & 1 & \multirow{2}{*}{.773} & .808 & .857 & \multirow[b]{2}{*}{$(10.543)$} & \multirow{2}{*}{.603} \\
\hline & 2 & & .859 & .741 & & \\
\hline \multirow{3}{*}{ Self-efficacy } & 1 & \multirow{3}{*}{.709} & .695 & .695 & & \multirow{3}{*}{.634} \\
\hline & 2 & & .813 & .601 & (8.708) & \\
\hline & 3 & & .784 & .805 & $(9.964)$ & \\
\hline \multirow{4}{*}{ Life-satisfaction } & 1 & \multirow{4}{*}{.884} & .784 & .768 & & \multirow{4}{*}{.795} \\
\hline & 2 & & .885 & .839 & (15.074) & \\
\hline & 3 & & .821 & .771 & (13.752) & \\
\hline & 4 & & 874 & .867 & $(15.570)$ & \\
\hline
\end{tabular}

\subsection{Hypothesis Test}

\subsubsection{Fit of research model}

The overall fit statistics of our hypothesized model mostly meet the conventional standards, indicating our model fits with data well (CMIN $/ \mathrm{DF}=2.918, \mathrm{CFI}=.918, \mathrm{IFI}=.919, \mathrm{TLI}=$ $889 \mathrm{NFI}=.882, \mathrm{RFI}=.840$, and RMSEA $=$ .079). Therefore, we concluded our model is acceptable to test the proposed relationship and proceeded to hypotheses test.

\subsubsection{Major results of hypothesis test}

Structural equation modeling analysis was conducted using AMOS program to test hypotheses. Major results of hypotheses test are presented in Figure 1.

As hypothesized, attachment to heroes has a stronger positive effect on self-efficacy than attachment to celebrities does. Path coefficient shows that relationship between attachment to heroes and self-efficacy is positive and significant $(\beta=.268, p<.001)$ while the relationship between attachment to celebrities and self-efficacy is not significant $(\beta=.079, p=$ 
〈Figure 1〉 The Result of Structural Model

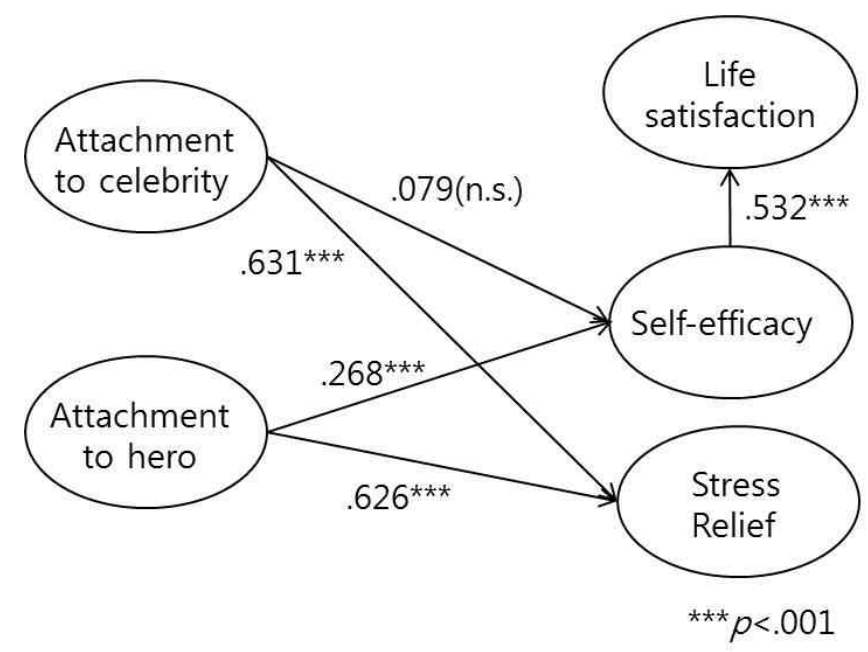

.279), in support of H1.

As for the effect of human brand attachment on stress relief, attachment to celebrities turned out to have a stronger effect on stress relief than attachment to heroes does. The path coefficient between attachment to celebrities and stress relief $(\beta=.631, p<.001)$ is greater than the path coefficient between attachment to heroes and stress relief $(\beta=.626$, $p<.001)$, in support of $\mathrm{H} 2$.

Last, self-efficacy turned out to have a positive effect on life satisfaction. The relationship between self-efficacy and life satisfaction is positive and significant $(\beta=.532, p<.001)$, in support of $\mathrm{H} 3$.

The combined results indicate that attachment to heroes have stronger influence on consumers' life satisfaction through self-efficacy in the long term, whereas attachment to celebrities have stronger influence on stress relief in the short term.

\section{Discussion}

This study examined how attachment toward heroes and celebrities affects his or her stress relief and life satisfaction through selfefficacy. As predicted, the attachment to heroes has a relatively stronger effect on self-efficacy than attachment to celebrities does, which in turn results in enhanced life satisfaction whereas attachment to celebrities has a stronger effect on stress relief than attachment to heroes does.

The results of our study remind us of the importance of heroes in people's self-efficacy and ultimately life satisfaction in general. Our results show that although celebrities draw at- 
tachment from people by providing fun and entertainment or getting rid of stress they have weak influence on the efficacy and well-being of individuals at a deeper level. However, attachment toward heroes helps people live better by providing meaning or influencing positively on the life satisfaction through self-efficacy (Frankl 1997). These results are consistent with the main tenet of 'positive psychology' which seeks "to find and nurture genius and talent and to make normal life more fulfilling" (Seligman and Csikszentmihalyi 2000). Considering the fact that sometimes certain celebrities are perceived as heroes for some people, we can conclude that celebrities can become heroes if they provide meaning and value to the lives of people.

\subsection{Contributions}

The results of this study provide both theoretical and managerial contributions. A significant theoretical contribution of this study is that it examines how attachment to a human brand has an effect on consumers' quality of life such as self-efficacy, life satisfaction, and stress relief. In addition, this study is the first attempt to address the outcome variables of the attachment in the sense that most of the existing studies on human brands focused on the antecedents of the attachment toward celebrities and heroes. This study contributes to the research stream of human brands since the most current leading research (e.g., Thomson 2006) indicated the need to look at the resulting effect of attachment on the life satisfaction in general. This study goes further by adding important outcome variables, self-efficacy and stress relief.

Another important theoretical contribution is that we empirically documented the different effects of celebrities and heroes. As expected, this study shows that heroes deeply influence the lives of individuals in the long term while celebrities do so rather shallowly in the short term. The issues of the influence of heroes on the individuals' lives need to be further investigated in relation with the perspective of positive psychology.

In addition to those academic contributions, there are significant managerial implications from this study. Studies in quality of life marketing clearly indicates that enhanced consumers' wellbeing results in positive word-of-mouth and company goodwill (Lee and Sirgy 2004; Szymanski and Henard 2001). This is because when customers perceive that a company tries to enhance their well-being, they feel that they can trust the company (Lee and Sirgy 2004). Therefore, more companies are interested in enhancing the well-being of their customers while preserving the well-being of the firm's other stakeholders (Lee and Sirgy 2004).

In this light, our study provides a way to enhance consumers' well-being as our results clearly indicate that the more consumers feel attached 
to human brands, especially heroes, the more the they feel well-being, especially in terms of self-efficacy and life satisfaction. The marketing practitioners who learn such implications from our study would better understand the importance of heroes for consumers. Therefore, the marketers could use heroes as endorsers or advertising models to make their brands more trustworthy in the long term rather than use popular celebrities as endorsers for short-term profitability.

Moreover, our additional study further revealed that attachment to human brands is positively related to supportive behavior for the brand they are endorsing. Since our focus is the effect of human brand attachment on aspects of consumers' quality of life, the direct effect of human brand attachment on supportive behavior for endorsing brands is not formally reported in this study. Because companies clearly benefit from human brand endorsers to whom consumers feel attached, the companies could make greater effort to strengthen the consumers' attachment to their endorsers such as holding a fan meeting on a regular basis. Through these effort, the companies can lead the consumers to build stronger attachment to the human brands endorsers, which may improve the brand supportive behavior of consumers.

\subsection{Limitations and Future Research}

We tentatively argue that attachment to ce- lebrities and heroes would have different effects based on the statistical result. Further studies are needed to document their different effects in a more rigorous way.

This study empirically showed that heroes positively influence life satisfaction through selfefficacy whereas celebrities do not. Since this result could be different under specific circumstances, searching for moderating variables would be meaningful in further studies. Theoretical examination could well-combine with the ultimate values, power, entertainment, and meaning, from the framework of Frankl (1997). For example, the relationship between attachment to celebrities and quality of life can be stronger for consumers who value entertainment most. On the contrary, the relationship between attachment to heroes and quality of life can be stronger for consumers who value meaning in life most.

As the influence of heroes on people is significant, examining the effect of hero endorsing on people's perception of corporate authenticity would be interesting. Because of the characteristics and values of heroes, it is expected that hero endorsing positively influences corporate authenticity. Heroes provide meaning in life and encouragement with credibility and symbolism. According to previous literature, the major characteristics of heroes are credibility, sincerity, and morality. These values are consistent with authenticity. Therefore, the characteristics and values of the hero can be transferred to the 
brand or company that they endorse or support.

There is another limitation and future direction. Although life satisfaction in general was measured according to the previous studies, a more formal measure of well-being could enhance the quality of research. The recent concept of Subjective Well-Being (SWB) index could be used to see how attachment toward human brands, especially heroes, influences the subjectively perceived well-being of ordinary people. It is hoped that future research will help people "to find and nurture genius and talent" and "to make normal life more fulfilling" (Seligman and Csikszentmihalyi 2000).

〈Received January 2. 2014〉

〈Revised February 14. 2014〉

$\langle$ Accepted February 15. 2014〉

\section{References}

Ahn, Kwang Ho and Jae Hwan Lee (2010), "The Influence of Consumer Need Satisfaction and Star Traits on Consumer Attachment to Star Brand and Consumer Response to Product Brand Sponsored by Star Brand," Asia Marketing Journal, 12 (1), 51-79.

Bagozzi, Richard P. and Youjae Yi, (1988), "On the Evaluation of Structural Equation Models," Journal of the Academy Marketing Science, 16, 1, 74-94.
Bagozzi, Richard P., Youjae Yi, and Phillips, W. Lynn (1991), “Assessing Construct Validity in Organizational Research," Administrative Science Quarterly, 36, 421-458.

Bandura Albert (1977), "Self-efficacy: Toward a Unifying Theory of Behavioral Change," Psychological Review, 84(2), 191-215.

Bandura, Albert (1997), Self-Efficacy: The Exercise of Control. New York: Freeman. Bandura Albert (2002), Social Foundations of thought and Action, In D.F. Marks (Eds.), The Health Psychology Reader (pp. 94106), London: Sage.

Belk, R. (1988), "Possessions and the Extended Self," Journal of Consumer Research, 15 (2), 139-168.

Bowlby, John (1988), A Secure Base: ParentChild Attachment and Healthy Human Development. New York: Basic Books.

Cohen, S., Kamarck, T. and Mermelstein, R. (1983), “A Global Measure of Perceived Stress," Journal of Health and Social Behavior, 24(4), 385-396.

Diener Edward, Robert A. Emmons, Randy J. Larsen, and Sharon Griffin (1985), "The Satisfaction with Life Scale," Journal of Personality Assessment, 49(1), 71-75.

Frankl, Viktor E. (1997), Man's Search for Meaning, Washington Square Press.

Holt, Douglas B. (2004), How Brands Become Icons, Harvard Business School Press.

Kobak, R., Cassidy, J., Lyons-Ruth, K. and Ziv, Y. (2006), Attachment, Stress, and 
Psychopathology: A Developmental Pathways Model, In Cicchetti D. and Cohen, D.J. (Eds.), Developmental Psychopathology (pp. 333-364), New Jersey: John Wiley \& Sons, Inc.

Kim, Chung K, Mina Jun, Miyea Kim and Jeongsoo Han (2010), “Strong Attachment toward Human Brand: Its Antecedents and Implication for the Quality of Life," Korean Journal of Consumer Studies, 21 (4). 241-275.

Kim, Chung K., Mina Jun, Jeongsoo Han, Miyea Kim, and Joshua Y. Kim (2013), "Antecedents and Outcomes of Attachment towards Smartphone Applications," International Journal of Mobile Communications, 11, 4, 393-411.

Klapp, Orrin E. (1969), Collective Search for Identity, New York: Holt.

Kumar, A., Rinwa, P., Kaur, G. and Machawal, L. (2013), "Stress: Neurobiology, Consequences and Management," Journal of Pharmacy and Bioallied Sciences, 5, 91-97. Lazarus, R.S., and Folkman, S. (1984), Stress, Appraisal and Coping. New York: Springer. Lee, Dongjin and GraceB. Yu (2011), “Developing a Subjective Measure of the Quality of City Life (QCL): The Case of Seoul," Asia Marketing Journal, 13(1), 1-26.

Lee, Dong-Jin and Joseph Sirgy (2004), "Quality of Life Marketing: Proposed Antecedents and Consequences," Journal of Macromarketing, 24 (1), 44-58.
MaCracken, Grant (1989), "Who Is the Celebrity Endorser? Cultural Foundations of the Endorsement Process," Journal of Consumer Research, 16(December), 310-320.

Maddux, James. E. and Meier, L. J. (1995), Self-Efficacy and Depression, In J. E. Maddux (Eds.), Self-Efficacy, Adaptation, and Adjustment: Theory, Research, and Application (pp. 143-169), New York: Plenum. Maddux, James (2009), Self-efficacy: The Power of Believing You Can, In Shane J. Lopez and Charles R. Snyder (Eds.), Oxford Handbook of Positive Psychology (pp. 335343), New York: Oxford University Press. North, Adrian, Victoria Bland, and Nicky Ellis (2005), "Distinguishing Heroes from Celebrities," British Journal of Psychology, 96, 39-52.

Nunnally, J.C. (1978), Psychometric Theory, 2nd ed., New York, McGraw Hill.

Oishi, S. and E. Diener (2001), "Goals, Culture, and Subjective Well-being," Personality and Social Psychology bulletin, 27, 1674-1682.

Park, C. Whan, D. J. MacInnins, and Joseph Priester (2006), "Beyond Attachments: Attachment and Consumer Behavior," Seoul Journal of Business, 12(2), 1-35.

Pleiss, Mary K. and John F. Feldhusen (1995), "Mentors, Role Models, and Heroes in the Lives of Gifted Children," Educational Psychologist, 30(3), 159-169.

Pretzinger, K. (1976), "The American Hero: Yesterday and Today," Humboldt Journal 
of Social Relations, 4, 36-40.

Reeves, J. L. (1988), Television Stardom: A Ritual of Social Typification, In J. W. Carey (Eds.), Media, Myths and Narratives: Television and the Press (pp. 140-160), Newbury Park, CA: Sage.

Rein, I., P. Kottler and M. Stoller (1987), High Visibility, New York: Dodd, Mead and Company.

Rindova, Violina P., Timothy G. Pollock, and Mathew Hayward (2006), "Celebrity Firms: The Social Construction of Market Popularity," Academy of Management Review, 31(1), 279-292.

Schwarzer, R., and Jerusalem, M. (1995), Generalized Self-Efficacy Scale. In J. Weinman, S. Wright, and M. Johnston (Eds.), Measures in Health Psychology: A User's Portfolio. Causal and Control Beliefs (pp. 35-37), Windsor, UK: NFER-NELSON. Seligman, Martin E.P. and Mihaly Csikszentmihalyi (2000), "Positive Psychology: An Introduction," American Psychologist, 55(1), 5-14. Shin, D.C., and D. M. Johnson (1978), “Avowed Happiness as an Overall Assessment of the Quality of Life," Social Indicators Research, 5, 475-492.

Sirgy, M. Joseph, H.L. Meadow and A. Coskun Samli (1995), Past, Present, and Future: An Overview of Quality of Life Research in Marketing, In M, J. Sirgy and A.C. Samli, Westport (Eds.), New Dimensions of Marketing and Quality of Life Research (pp. 335-364), CT: Greenwood Press. Steyn, Renier and Johan Mynhardt (2008), "Factors that Influence the Forming of Self-evaluation and Self-Efficacy Perceptions," South African Journal of Psychology, 38 (3), 563-573.

Sullivan, Michael and Anre Venter (2005), "The Hero Within: Inclusion into the Self," Self and Identity, 4, 101-111.

Szymanski, David M., and David Henard (2001), "Consumer Satisfaction: A Meta-Analysis of the Empirical Evidence," Journal of the Academy of Marketing Science, 29, 16-35.

Thomson, Matthew, Deborah J. MacInnis and C. Whan Park (2005), "The Ties that Bind: Measuring the Strength of Consumers' Emotional Attachments to Brands," Journal of Consumer Psychology, 15(1), 79-91.

Thomson, Matthew (2006), "Human Brands: Investigating Antecedents to Consumers' Strong Attachments to Celebrities," Journal of Marketing, 70(July), 104-119.

Wallendorf, Melane and Eric J. Arnould (1988), "My Favorite Things: A Cross Cultural Inquiry into Object Attachment, Possessiveness, and Social Linkage," Journal of Consumer Research, 14(March), 531-547.

Watson, David, Lee A. Clark, and Auke Tellegen (1988), "Development and Validation of Brief Measures of Positive and Negative Affect: The PANAS Scales," Journal of Personality and Social Psychology, 54, 10631070. 